\title{
Jews on trial
}

The Papal Inquisition in Modena, 1598-1638

KATHERINE ARON-BELLER

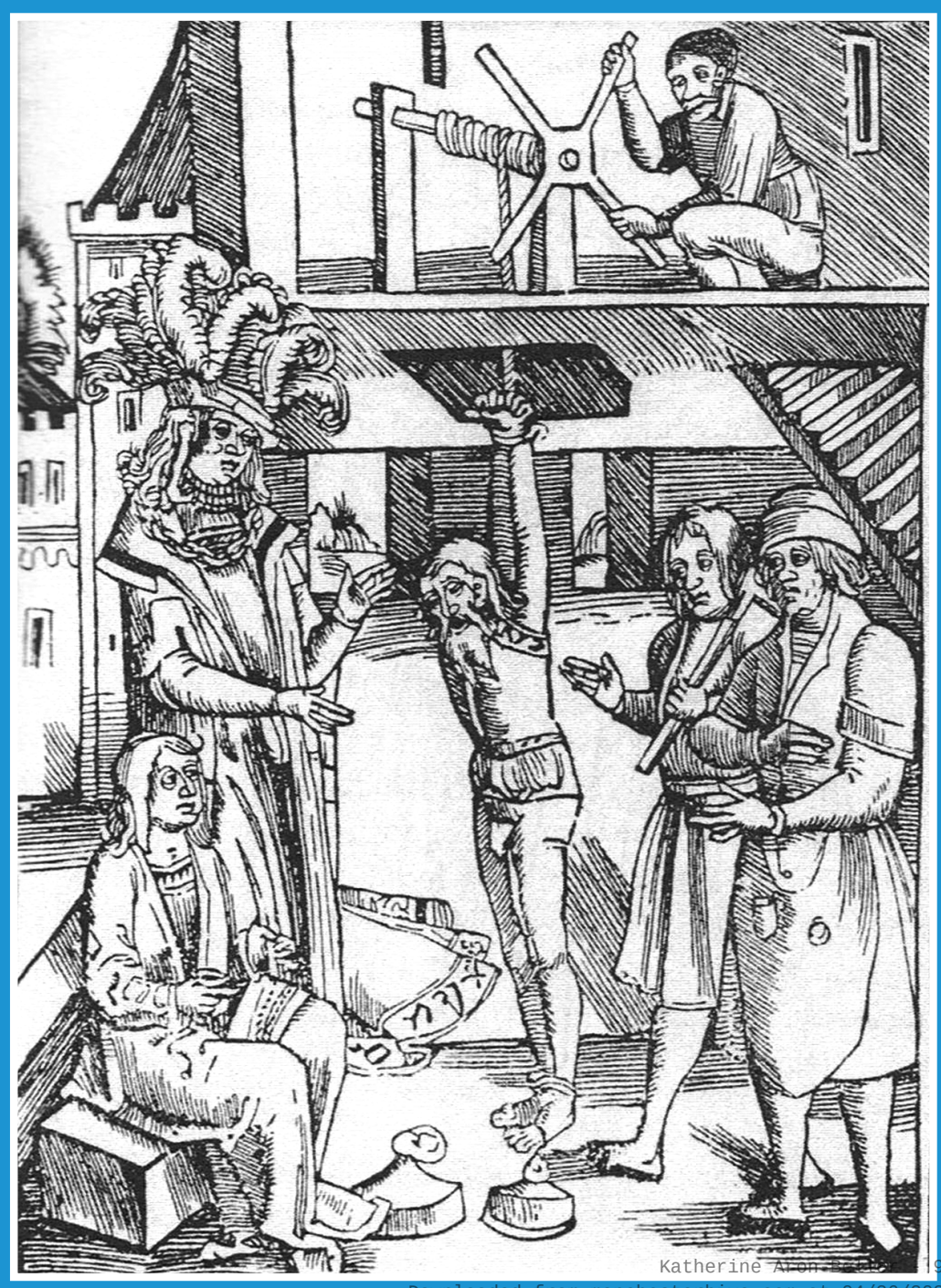




\section{Jews on trial}

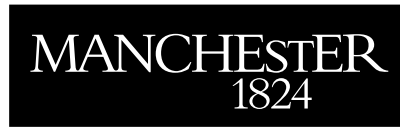

Manchester University Press 


\section{STUDIES IN EARLY MODERN EUROPEAN HISTORY}

This series aims to publish

challenging and innovative research in all areas of early modern continental history.

The editors are committed to encouraging work

that engages with current historiographical debates, adopts an interdisciplinary

approach, or makes an original contribution to our understanding of the period.

SERIES EDITORS

Joseph Bergin, William G. Naphy, Penny Roberts and Paolo Rossi

Also available in the series

Sodomy in early modern Europe ed. Tom Betteridge

The Malleus Maleficarum and the construction of witchcraft

Hans Peter Broedel

Latin books and the Eastern Orthodox clerical elite in Kiev, 1632-1780

Liudmila V. Charipova

Fathers, pastors and kings: visions of episcopacy in seventeenth-century France

Alison Forrestal

Princely power in the Dutch Republic:

Patronage andWilliam Frederick of Nassau (1613-64)

Geert H. Janssen, trans. J. C. Grayson

Representing the King's splendour: Communication and reception

of symbolic forms of power in viceregal Naples

Gabriel Guarino

The English Republican tradition and eighteenth-century France:

between the ancients and the moderns Rachel Hammersley

Power and reputation at the court of Louis XIII:

the career of Charles d'Albert, duc de Luynes (1578-1621) Sharon Kettering

Popular science and public opinion in eighteenth-century France

Michael R. Lynn

Catholic communities in Protestant states: Britain and the Netherlands c.1570-1720

eds Bob Moore, Henk van Nierop, Benjamin Kaplan and Judith Pollman

Religion and superstition in Reformation Europe

eds Helen Parish and William G. Naphy

Religious choice in the Dutch Republic: the reformation of Arnoldus Buchelus (1565-1641)

Judith Pollman

Witchcraft narratives in Germany: Rothenburg, 1561-1652

Alison Rowlands

Orangism in the Dutch Republic in word and image, 1650-1675

Jill Stern

Authority and society in Nantes during the French Wars of Religion, 1559-98

Elizabeth C. Tingle

The great favourite: the Duke of Lerma and the court

and government of Philip III of Spain, 1598-1621

Patrick Williams 


\title{
Jews on trial \\ The Papal Inquisition in Modena, 1598-1638
}

\section{KATHERINE ARON-BELLER}

\author{
Manchester University Press \\ Manchester
}


Copyright (C) Katherine Aron-Beller 2011

The right of Katherine Aron-Beller to be identified as the author of this work has been asserted by her in accordance with the Copyright, Designs and Patents Act 1988

This electronic version has been made freely available under a Creative Commons (CC-BY-NC-ND) licence, which permits non-commercial use, distribution and reproduction provided the author(s) and Manchester University Press are fully cited and no modifications or adaptations are made. Details of the licence can be viewed at https://creativecommons.org/licenses/by-nc-nd/4.0/

Published by Manchester University Press Altrincham Street, Manchester M1 7JA, UK

www.manchesteruniversitypress.co.uk

British Library Cataloguing-in-Publication Data

A catalogue record for this book is available from the British Library

Library of Congress Cataloging-in-Publication Data applied for

ISBN 9780719085192 hardback

First published 2011

The publisher has no responsibility for the persistence or accuracy of URLs for any external or third-party internet websites referred to in this book, and does not guarantee that any content on such websites is, or will remain, accurate or appropriate.

Typeset in Perpetua with Albertus display

by Koinonia, Manchester 